\title{
A trajetória da economia mundial: da recuperação do pós-guerra aos desafios contemporâneos
}

The trajectory of the world's economy: from recovery in the post-war period to contemporary challenges

Ricardo Carlos Gaspar

\section{Resumo}

0 presente texto constitui uma tentativa de interpretação dos múltiplos fenômenos que caracterizaram o período pós-guerra e as dinâmicas e vetores que levaram, a partir dos anos 1970, às profundas transformações que todos vivenciamos hoje. Na primeira seção, recuperamos os aspectos principais que demarcaram o advento da modernidade e a consolidação do sistema-mundo capitalista, com ênfase nas grandes mudanças econômicas do final do século XIX e início do século XX, bem como nas décadas de crise da primeira metade do século anterior. Nas quatro seções seguintes, repassamos criticamente todos os acontecimentos mais importantes ao longo da trajetória da economia global, do pós-guerra até a atualidade (início da segunda década do século XXI). Finalizamos com uma tentativa de avaliação da contemporaneidade, realçando os dilemas que a humanidade tem pela frente.

Palavras-chave: sistema-mundo moderno; urbanização; crises de hegemonia; globalização financeira; reestruturação produtiva.

\begin{abstract}
The present article is an attempt to understand the multiple phenomena that characterized the post-war period and the dynamics and forces that have led, since the 1970s, to the deep transformations that all of us have been undergoing. In the first section, we address the main aspects that delimited the advent of modernity and the consolidation of the capitalist world-system, emphasizing the great economic changes at the end of the 19th century and beginning of the 20th century, as well as the decades of crisis in the first half of the past century. In the following four sections, the analysis focuses critically on the most important events throughout the trajectory of the global economy, from the post-war period to the present (the beginning of the second decade of the 21st century). We conclude with an assessment of contemporaneity, trying to emphasize the dilemmas that humanity will have to face ahead.
\end{abstract}

Keywords: modern world-system; urbanization; hegemony crisis; financial globalization; productive restructuring. 


\section{Introdução}

0 presente texto constitui uma tentativa de interpretação dos múltiplos fenômenos que caracterizaram o período pós-guerra e as dinâmicas e vetores que levaram, a partir dos anos 1970 do século passado, às profundas transformações que todos vivenciamos hoje. A intenção foi elaborar um texto compreensível sem abdicar do rigor e do senso crítico. Na primeira seção, recuperamos os aspectos principais que demarcaram o advento da modernidade e a consolidação do sistema-mundo capitalista, com ênfase nas grandes mudanças econômicas do final do século XIX e início do século $X X$, bem como nas décadas de crise da primeira metade do século anterior. Nas quatro seções seguintes, repassamos criticamente todos os acontecimentos mais importantes ao longo da trajetória da economia global, do pós-guerra até a atualidade (início da segunda década do século XXI). Finalizamos com uma tentativa de avaliação da contemporaneidade, realçando os dilemas que a humanidade tem pela frente. $A$ abordagem é multidisciplinar, com ênfase para a dimensão e o substrato econômico dos fatos. Como a interpretação desses acentua seu aspecto qualitativo, prescindimos do uso de gráficos e tabelas, pois ampliariam de forma desmedida o tamanho e o escopo do texto.

Cabe ressaltar ainda que o estilo fluído de descrição e análise dos acontecimentos aqui adotados privou-se do travamento excessivo do texto com referências e citações bibliográficas mais detalhadas e extensivas. Elas não se adequariam bem na composição livre da escrita. Contudo, estão relacionadas, ao longo do artigo e na bibliografia, ao final, algumas das principais obras pertinentes aos temas enfocados.

\section{Antecedentes: formação do sistema-mundo moderno}

A ascensão das cidades medievais como centros de troca e atração populacional, entre os séculos XIII e XV, e a posterior dominância das práticas mercantilistas, configurando a aliança entre a emergente classe dos comerciantes e a realeza, deu origem aos poderosos estados europeus centralizados, impulsionadores do intercâmbio universal e da formação dos grandes impérios coloniais que mudaram a face do mundo nos albores da modernidade. Eles integraram, pela primeira vez na história da humanidade, a economia global em um único sistema. Tais fenômenos, por sua vez, constituíram o pano de fundo da consolidação da burguesia como classe hegemônica e da eclosão da Revolução Industrial na Inglaterra, no século XVIII (Braudel, 1987).

Com a Revolução Industrial, a base material da economia transformou-se radicalmente. 0 avanço na divisão do trabalho e na produtividade da economia permitiu que a Inglaterra garantisse sua supremacia global por mais de um século, até que o contágio da industrialização atingisse seus concorrentes potenciais - sobretudo os Estados Unidos e a Alemanha - depois da segunda metade do século XIX.

A mudança de paradigma tecnológico, no final do século XIX, inaugurou uma nova fase na industrialização global. A grande indústria afirma-se com a introdução de métodos de 
trabalho em série, com a gerência científica e a fragmentação das tarefas do trabalhador, do mesmo modo que a constituição de poderosos oligopólios mina a ideia de um mercado concorrencial perfeito. À era do carvão e da energia a vapor se superpõe a era da eletricidade, do aço e do petróleo. Essa nova revolução industrial ocorre em paralelo a uma intensa luta pelo poder mundial, cuja tradução maior está expressa na corrida armamentista e nas fortes políticas protecionistas que opõem os principais estados uns aos outros. As duas guerras mundiais (de 1914-18 e 1939-45) são o resultado dessas tensões (Chang, 2004; Tilly, 1996).

0 acirramento do conflito social ainda produziria um acontecimento cujas repercussões abarcaram a maior parte do século: a Revolução Russa de 1917, que veio a ser a primeira revolução socialista de caráter marxista bem-sucedida no contexto de uma nação. Embora pauperizada, a Rússia da época fazia parte do bloco dos países mais poderosos do planeta. Acresce ao cenário de graves tensões da primeira metade do século passado a Grande Depressão de 1930, uma crise tipicamente capitalista, testemunha do fracasso dos padrões liberais que ainda guiavam a conduta dos agentes políticos e econômicos da época. Se, por um lado, os contornos de um novo padrão de crescimento já claramente se delineavam (a produção em massa), por outro, a impotência dos governos, a falta de confiança dos agentes econômicos (que bloqueava o crédito) e os conflitos interestatais pela hegemonia global impediam sua plena cristalização nas décadas de crise mundial. Um novo modelo tornava-se imperativo. 0 capitalismo, para sobreviver, precisava ser profundamente reformado. $E$ isso ocorreria depois do final da II Grande Guerra.
Depois de décadas de crises e guerras que desestabilizaram gravemente o sistema capitalista, do colapso do liberalismo decorreram reformas profundas capazes de aparelhar os estados com instrumentos de ação efetivos sobre a economia e os sistemas produtivos. Nas próximas seções, buscamos sumariar as características mais importantes de uma época de esperanças e frustrações, de radicais mudanças econômicas e sociais de âmbito planetário.

\section{A trajetória da economia mundial: as mudanças do pós-guerra}

\section{Os acordos de Bretton Woods: crescimento e controle financeiro}

Após as experiências traumáticas da primeira metade do século XX e das constantes ameaças de colapso sistêmico, fracassos esses associados acima de tudo à patente incapacidade da concepção liberal em lidar com as novas realidades econômicas, e ante a aproximação do final da II Grande Guerra e a vitória dos aliados, delegados de 44 nações se reuniram na cidade britânica de Bretton Woods, em julho de 1944. Naquela ocasião, foram definidas as bases de gerenciamento econômico internacional do pós-guerra e fixadas as regras para as relações comerciais e financeiras entre os países mais industrializados do mundo. Ficou estabelecida a indexação da taxa de câmbio das principais moedas em relação ao dólar e uma paridade fixa desse em relação ao ouro. Novas instituições foram criadas, como o Banco Internacional para a Reconstrução e 
o Desenvolvimento - BIRD -, o atual Banco Mundial, e o Fundo Monetário Internacional FMI. 0 sistema de Bretton Woods foi o primeiro exemplo, na história mundial, de uma ordem monetária totalmente negociada, tendo como objetivo governar as relações monetárias entre estados-nações independentes. No esforço de promover a cooperação internacional sobre uma base consensual e estável, deve ser citada, também, a criação, em 1945, da Organização das Nações Unidas - ONU.

A prioridade da economia capitalista passava a ser garantir, de forma sustentada, o crescimento mundial e a elevação dos níveis de emprego. Para isso, era preciso reestruturar as instituições existentes e criar outras novas, tanto no âmbito interno dos países, quanto no internacional. Nesse último, buscava-se constituir um sistema multilateral, estabelecido sobre parâmetros cambiais pré-definidos, agora utilizando o dólar americano como padrão monetário internacional.

Mas esse plano, coordenado pelos Estados Unidos, teve que ser adiado. Ao final da II Guerra, da qual o território e os recursos norte-americanos saíram praticamente intactos, os Estados Unidos concentravam sozinhos a quase totalidade da liquidez mundial. Seu território continental não havia sido atacado, e sua infraestrutura e malha industrial saíram ilesas. Os Estados Unidos se tornaram o maior credor global (na verdade, condição presente desde o final da I Guerra). Numa situação tão assimétrica, não haveria possibilidade de instituir qualquer sistema de comércio multilateral e equilíbrio interestatal minimamente saudável. Um período de transição foi assim instaurado, dentro do qual os Estados Unidos injetaram vultosas somas de recursos para reconstruir as principais economias capitalistas devastadas pelo conflito bélico, pelo Plano Marshall. Recursos a fundo perdido, direcionados especialmente para Japão e Alemanha (Fiori, 1999).

Nesse esforço de reconstrução econômica, a ameaça comunista veio a calhar. A União das Repúblicas Socialistas Soviéticas - URSS, apesar das enormes perdas humanas e materiais sofridas durante a guerra, emergiu do conflito com muito prestígio e viu seu poderio político aumentar consideravelmente com a incorporação de países da Europa oriental ao bloco socialista e, em 1949, com a vitória da revolução comunista na China. Essa nova realidade geopolítica planetária, de cunho ideológico, aliada ao confronto militar que irrompeu na Coreia no início da década de 1950, forneceu o pretexto para maciças injeções de recursos norte-americanos para o fortalecimento de sua capacidade bélica, o que envolvia gigantescas transferências ao exterior com fins bélicos. Era a guerra fria, que marcou a política e a economia globais na segunda metade do século XX. Na perspectiva estritamente político-militar, constituíram-se blocos opostos. De um lado, o Pacto de Varsóvia, uma aliança militar formada pela URSS e os países socialistas do leste europeu, com exceção da lugoslávia (a Albânia viria a deixar a aliança anos mais tarde). De outro, a Organização do Tratado do Atlântico Norte - OTAN, que uniu as nações capitalistas da Europa Ocidental e os Estados Unidos para prevenir e defender países membros de eventuais ataques vindos do leste comunista. A ameaça de conflito nuclear pairou sobre a humanidade ao longo de todo o período de vigência da guerra fria.

É conveniente ressaltar que o gasto público propiciado pela economia de guerra deu 
um poderoso e decisivo impulso à fase de expansão material da economia capitalista do pós-guerra. Ela não apenas foi responsável pelo desenvolvimento de novos setores, principalmente o eletro-eletrônico, o qual derivou de inovações técnicas resultantes da pesquisa militar, como ainda possibilitou o incremento sustentável da demanda de duráveis até os anos 1960, viabilizada pela contenção relativa de seu consumo durante a guerra (Hirst e Thompson, 1998).

\section{Keynes: pleno emprego, demanda efetiva, gasto público}

De todo modo, novos tempos implicavam novas políticas e novas instituições. 0 economista inglês John Maynard Keynes (1883-1946) personificou uma abordagem econômica que, no âmbito das economias de mercado, rompeu com a interpretação neoclássica até então predominante, na academia e no establishment dos países industrializados. Para Keynes, a interpretação liberal era válida nos seus pressupostos quando aplicada a uma situação social que não mais prevalecia no contexto econômico do século $X X$, marcada por monopólios e recorrentes fenômenos de concorrência imperfeita. Impunham-se diagnósticos e terapêuticas distintas para salvar as economias de mercado. 0 combate às práticas rentistas, bem como ao desemprego e à crônica subutilização dos fatores produtivos, enfatizava a retomada do crescimento sustentado em primeiro plano.

Keynes consagrou o primado da demanda efetiva adiante da economia da oferta neoclássica. Nesse sentido, a prioridade passa a recair agora sobre os fatores capazes de elevar os níveis de renda e de emprego do sistema. 0 volume de investimento cria e determina os patamares de sua própria poupança agregada. Como as premissas keynesianas se deslocam para os fundamentos da eficiência sistêmica no sentido de atingir níveis substantivos de investimento, utilização da capacidade ociosa, criação bruta de capital fixo, emprego dos fatores e desempenho do consumo, a visão macro da economia se instaura e, com ela, surge 0 imperativo de medir os agregados macroeconômicos, sobretudo o produto nacional bruto. Embora, é claro, na lógica capitalista, a concepção de Keynes representou uma guinada radical em relação aos padrões anteriores do equilíbrio automático e do livre jogo da oferta e da procura. Implicava, por fim, uma nova postura do Estado, como agente coordenador, normatizador e investidor, e dotado de instrumentos totalmente novos de intervenção na economia, como as políticas fiscal e monetária. Em suma, o objetivo era garantir economias de mercado prósperas, de pleno emprego dos recursos produtivos, reguladas, nas quais o gasto público assumia papel fundamental.

0 novo padrão produtivo, com base na produção e no consumo de massa, elevada capacidade de geração de emprego e uso intensivo de energia, encontra assim as condições propícias para se generalizar. Consolidam-se os princípios tayloristas e fordistas de organização do trabalho.

\section{Estado do Bem Estar Social}

0 crescimento econômico vigoroso, a geração maciça de empregos, a elevação da renda e a incorporação de milhões de trabalhadores ao 
mercado de consumo verificada nos países centrais do capitalismo não teriam sido possíveis sem a colocação em prática de um mecanismo político, comandado pelos respectivos estados nacionais, pelo qual foi estabelecida uma espécie de pacto social tripartite, englobando governo, empresários e trabalhadores. Esse pacto esteve na base da existência do Welfare State, ou Estado do Bem Estar Social, e nele os empresários entravam com os empregos, salários em níveis aceitáveis e com repasse - ao menos parcial - dos ganhos de produtividade, e investimentos na elevação da capacidade produtiva. Os trabalhadores, por sua vez, além de garantirem o cumprimento das cláusulas previstas nos seus contratos de trabalho, comprometiam-se a moderar suas reivindicações e circunscrevê-las nos estritos marcos das economias de mercado. Por fim, 0 governo entrava como avalista dessas condições e, por intermédio de um sistema tributário fortalecido, transformar receitas fiscais em bens e serviços públicos à classe operária.

Essa estratégia política tinha como pano de fundo o propósito de afastar trabalhadores, suas lideranças e organizações (os sindicatos) dos comunistas, pois os socialistas (a social-democracia) já haviam sido em boa medida neutralizados como força antissistêmica desde o limiar da II Guerra. E, de fato, as reivindicações trabalhistas, desde então, e por mais contundentes que se apresentassem, sempre se circunscreveram nesses limites, relegando o movimento sindical de esquerda nos países ricos - com poucas exceções - a um papel secundário ou mesmo inexistente em termos das relações de poder.

Constitui-se, assim, um poderoso círculo virtuoso em que cada elemento potencializa e é alimentado pelos demais. Crescimento econômico, elevação da produtividade, investimento estatal, incorporação dos trabalhadores aos frutos do progresso, são todos fatores que o Estado do Bem Estar Social veio consolidar politicamente. Para os assalariados, a redistribuição de renda traduziu-se em garantias trabalhistas, previdência e assistência social, educação e saúde subsidiadas, habitação popular, mobilidade e acessibilidade urbanas, equipamentos públicos de lazer. Essa lógica de ação estatal também se verificou em alguns países periféricos selecionados, como - no caso da América Latina - no Brasil, Argentina e México, nessa ordem de importância. Nesses, porém, seu alcance e significado foram muito mais restritos que nos países capitalistas industrializados, seja pela dimensão limitada de seu mercado formal de trabalho, seja pelo fato de sua taxa de exploração da mão de obra ser mais elevada, tendo em vista sua origem colonial.

\section{0 poderoso bloco socialista}

Por seu turno, o bloco socialista liderado pela URSS (o "segundo mundo") iniciava um vigoroso processo de reconstrução de seus países devastados pela guerra. A União Soviética, em particular, extrapolou seu projeto de poder mundial anticapitalista originário da Revolução de Outubro de 1917, dessa vez não mais centrado na sublevação dos povos, mas principalmente no âmbito da competição interestatal pela hegemonia global. Tal projeto pressupunha ingentes esforços de aparelhamento tecnológico e militar, o que, nas bases stalinistas (de Josef Stalin, mandatário soviético, 1878-1953) do regime, implicava a exacerbação das brutais 
condições de exploração dos recursos laborais (até então escassos, pelas perdas humanas da Il Guerra) do país. A carga de sacrifício exigida dos trabalhadores soviéticos teve um ponto de inflexão decisivo com a coletivização agrícola forçada iniciada em 1929, que consolidou no poder um estrato burocrático-gerencial considerado por muitos analistas como a nova classe dirigente na URSS, minando o propósito da construção de uma autêntica democracia socialista. Ressalte-se que a debilidade das bases materiais originárias havia sido uma marca histórica constitutiva da primeira revolução socialista do mundo, ocorrida em um país relativamente pobre e periférico, em termos de capacidade industrial e do peso da classe operária.

A China, por sua vez, tampouco escapou das vicissitudes da revolução em país pobre e atrasado, o que implicava métodos cruéis de acumulação (não raro primitiva), o que contrariava as predições de Marx, para quem o cenário provável e apropriado da revolução socialista pressupunha a acumulação do máximo de riqueza propiciada pelo sistema capitalista e, assim, a distribuição social em bases técnicas avançadas. A transformação da China, iniciada com a vitória do movimento liderado por Mao Tsé-Tung (1893-1976) em 1949, nos primeiros anos inseriu-se na órbita de influência soviética. Com a morte de Stalin e o XX Congresso do Partido Comunista da URSS (1956), que denunciou os crimes da era stalinista, a República Popular da China explicitou suas crescentes divergências geopolíticas e doutrinárias com a URSS, que, poucos anos depois, levaram à ruptura das relações e até a ameaça de guerra entre as duas potências.

Tanto no caso da URSS e dos países sob sua esfera de influência direta - que incluíam, fundamentalmente, os países da Europa Oriental, aos quais se somariam, anos depois, Cuba e mais algumas nações na Ásia e na África -, como no caso da China, o bloco socialista como um todo apresentou vigorosas taxas de crescimento econômico até os anos 1960, pois se tratava da construção dos estágios iniciais da industrialização pesada, o departamento de bens de capital, e da incorporação forçada da quase integralidade dos recursos nacionais para atingir tal objetivo.

No plano político, o movimento popular de esquerda havia logrado construir, no imediato pós-guerra, fortes partidos socialistas e comunistas que constituíam alternativas reais de poder em muitos países. No caso das nações capitalistas ricas, essa "ameaça" foi afastada pela combinação de crescimento econômico e mecanismos de distribuição de renda propiciados pelo Estado do Bem Estar Social, de que falaremos adiante. Quanto ao mundo subdesenvolvido e periférico, a luta revolucionária, que muitas vezes assumia a luta armada como estratégia de ação, só podia ser contida com um misto de feroz repressão e táticas de cooptação. Seja como for, pode-se concluir que a guerra fria dominou a política internacional até 0 fim da década de 1980, ao contrapor distintas visões de mundo e estratégias de poder, materializadas na adesão aparentemente irredutível dos Estados a um dos dois lados da disputa Estados Unidos ou URSS (Hobsbawm, 1995).

\section{Terceiro Mundo}

0 Terceiro Mundo compreendia o conjunto de nações não pertencentes ao núcleo capitalista hegemônico - ao qual se somavam a 
periferia dos países capitalistas europeus dependentes, como Portugal, Espanha, Itália e Grécia - e aqueles não pertencentes ao bloco socialista. Agrupava estados que integraram vastos impérios coloniais, povos subjugados por séculos de colonialismo e atraso, que buscavam, com a vaga da descolonização do pós-guerra e as reformas (e revoluções) características do período, um rumo autônomo de desenvolvimento econômico e social. Atualmente, essa ampla periferia foi renomeada pelos organismos internacionais como "países em desenvolvimento".

Ademais, não raras vezes a independência ou a deposição de regimes títeres do imperialismo foi resultado também de lutas de libertação nacionais, lutas armadas conduzidas por partidos ou movimentos que tinham o nacionalismo - com conotações mais ou menos socializantes - como bandeira. 0 nacionalismo como ideário político constituía um amálgama de concepções de poder e sociedade muitas vezes contraditório, com programas genéricos, mas que significava talvez a única via ideológica apta a unir populações tão heterogêneas, parte delas escassamente integrada no curso da modernidade triunfante.

0 nacionalismo incorporado nos discursos, objetivos econômicos e na constituição dos novos países e governos surgidos no pós-guerra foi inevitavelmente traduzido em planos ambiciosos de desenvolvimento - também objeto de disputas acirradas entre Estados Unidos e URSS visando apoio e financiamento -, cujo objetivo era, a um só tempo, recuperar o atraso histórico, elevar o padrão de vida de seus povos e garantir a autonomia de decisões sobre seus próprios destinos, por meio da industrialização de base, do fomento agrícola (usualmente pela reforma agrária) e do fortalecimento do mercado interno (Hobsbawm, 1995).

Na América Latina, a Comissão Econômica para a América Latina - Cepal, organismo da ONU, incorporou criativamente a teoria da concorrência imperfeita e o pensamento de Keynes, provenientes do colapso do liberalismo, para formular um pensamento original sobre a natureza do subdesenvolvimento que assolava nossas nações e propor saídas para sua superação.

De acordo com a Cepal - que teve entre seus principais expoentes o economista argentino Raul Prebisch (1901-1986) e o brasileiro Celso Furtado (1920-2004) -, o subdesenvolvimento não era um estágio na longa trajetória do desenvolvimento que todos os países teriam que percorrer. 0 subdesenvolvimento, pelo contrário, era uma condição, a qual só poderia ser superada rompendo-se com a divisão internacional do trabalho que delegava a um grupo de países - o centro capitalista - a produção industrial, e ao outro grupo, o fornecimento de matérias-primas agrícolas e minerais. Diferentemente do que preconizava a teoria das vantagens comparativas, semelhante especialização do comércio internacional não levava à prosperidade geral, mas sim ao empobrecimento e atraso de uns (a periferia) e à concentração dos frutos do progresso técnico nos países centrais. Era uma situação crônica que perpetuava a miséria e a dependência da periferia. Mesmo que uma elevação da produtividade se verificasse nos países pobres, os ganhos daí oriundos seriam exportados ao centro do sistema, cuja diversificação da estrutura produtiva as tornava aptas para absorver a demanda de bens de consumo e de equipamentos provenientes da periferia. E qual era a saída para os países dependentes 
trilharem um caminho de progresso e internalizarem os frutos do progresso técnico?

A resposta era: a industrialização, única via capaz de propiciar a superação do atraso histórico e do subdesenvolvimento periférico. Pelos encadeamentos para trás e para frente, a indústria possibilitaria a almejada difusão do progresso técnico e a elevação da renda da população. Elevada a categoria de um verdadeiro mito para os cepalinos e para todas as vertentes da esquerda latino-americana que beberam dessa fonte, a industrialização não prescindiria do apoio do capital externo que estivesse disposto a romper com o modelo primário-exportador dominante e iniciar uma trajetória de crescimento para dentro. Contudo, na ausência de um empresariado nacional forte, caberia unicamente ao Estado a tarefa de comandar o processo, seja mobilizando o capital necessário, seja investindo diretamente para gerar os impulsos industrializantes por meio da constituição da indústria pesada.

0 interessante no caso da Cepal é que a teoria virou prática em muitos países latino-americanos e influenciou concepções e programas de ação em outras partes do mundo subdesenvolvido. No Brasil, à época do segundo governo Getúlio Vargas (1951-1954), bem como no período presidencial de Juscelino Kubitschek e seu Plano de Metas (1956-1960), 0 avanço da industrialização teve direta inspiração das prédicas cepalinas. Contudo, como veremos mais adiante, e apesar dos avanços logrados na diversificação e modernização no caso da economia brasileira, seus efeitos estiveram longe do preconizado no tocante à disseminação de efeitos positivos sociais e territoriais, e mesmo no que se refere à superação da dependência externa.

\section{Resultantes}

Depois de décadas de crises e guerras que desestabilizaram gravemente o sistema capitalista, decorreram do colapso do liberalismo reformas profundas capazes de aparelhar os estados com instrumentos de ação efetivos sobre a economia e os sistemas produtivos.

Nos países capitalistas ricos (o "primeiro mundo"), a demanda reprimida durante os vários anos de crise e guerra, as tecnologias da produção em massa, a regulação macroeconômica e o gasto público prepararam o terreno para décadas de crescimento vigoroso e distribuição de renda, período de estabilidade que ficou conhecido como golden age. Durante um quarto de século, a inserção social por intermédio do trabalho assalariado, a criação de um ambiente monetário estável, subordinando as finanças às necessidades da indústria, e a centralidade dos estados nacionais como reguladores da economia em geral, e do capital privado, em particular, asseguraram a expansão da acumulação capitalista (Fiori e Medeiros, 2001; Tavares e Fiori, 1997).

No que diz respeito ao "milagre" asiático, esse se manifestou no Japão na década de 1960, expandindo-se para a Coréia do Sul, Taiwan, Hong Kong e Singapura nos anos 1970. Na década seguinte, o sistema de subcontratação de múltiplas camadas sobre o qual se baseava passou a abarcar outros países asiáticos, como a Indonésia, a Tailândia e, principalmente, a China. 0 acesso do Japão à tecnologia de ponta, à proteção militar, aos financiamentos subsidiados e aos mercados das nações ricas, propiciado pelos Estados Unidos no contexto da estratégia de contenção do comunismo no pós-guerra, garantiu-lhe condições de largada 
altamente favoráveis e sustentou crescentes excedentes comerciais junto ao vigoroso mercado norte-americano (Arrighi, 2008).

Já no caso do bloco socialista, a construção (ou reconstrução) dos estágios iniciais da industrialização sob rígido controle estatal do excedente e da acumulação também propiciou décadas de crescimento rápido e pleno emprego.

As mesmas condições prevalecentes em países socialistas com padrão de planejamento central soviético podem ser parcialmente aplicadas para o caso de certos países do terceiro mundo que adotaram o controle estatal do processo de acumulação produtiva e da construção da indústria de bens de capital. Também aqui se verificaram altos índices de elevação do produto interno no pós-guerra. À diferença do bloco socialista, na industrialização periférica, quando bem-sucedida (como no caso do Brasil), o setor privado - principalmente de origem multinacional - complementou e, em muitos sentidos, direcionou a própria ação desenvolvimentista do Estado nacional.

Por último, mesmo no terceiro mundo mais pobre, os planos de desenvolvimento, a reforma agrária, as recomposições demográficas, os investimentos públicos e a cooperação internacional propiciaram anos de esperança em um futuro melhor para seus povos, em boa medida frustrados depois da crise dos anos 1970.

Regra geral, as duas ou três décadas do pós-guerra foram um período de mudanças generalizadas e de duradouro crescimento econômico. A ideia de um verdadeiro desenvolvimento com distribuição de renda que significasse melhorias concretas no padrão de vida das populações parecia estar se convertendo em realidade, independentemente do modelo político adotado. Em todas as situações encontradas, porém, um denominador comum podia ser identificado: o protagonismo estatal, o controle público sobre as decisões de investimento, a noção - tornada prática - de que a economia de mercado poderia e deveria ser domada em prol do bem comum.

\section{Os anos 1960: auge do crescimento e tensões}

\author{
Sintomas de crise: mercados, \\ salários, preços, lucros
}

A mudança permanente é característica intrínseca à existência. Inexiste situação vital, por mais estável que aparente ser, que não carregue em si as sementes de sua própria transformação. Isso vale tanto para a vida orgânica quanto para a inorgânica. Tanto para a vida animal quanto para a humana. 0 ciclo virtuoso da economia mundial nas décadas do pós-guerra não podia fugir à regra. Os anos dourados nos países capitalistas centrais fez avolumar, com o tempo, sérias contradições subjacentes, parcialmente obscurecidas nos anos de fartura. Lembremos que esse núcleo rico era política e economicamente hegemônico no sistema global, pois as economias de planejamento central imitavam a tecnologia e suas diversas aplicações, derivadas do padrão americano de acumulação.

A era de crescimento contínuo e a aparente superação das crises capitalistas se alimentavam de uma série de condições que se reforçavam mutuamente: alto nível de 
investimentos, lucros elevados, salários e empregos compatíveis com a plena ocupação da força de trabalho e com o incremento permanente da capacidade aquisitiva da população. No final dos anos 1960, o ciclo de crescimento do pós-guerra estava no seu clímax, e as tensões começaram a exacerbar-se.

No final dos anos 1960, os fatores positivos do crescimento exponencial começaram a transmutar-se em negativos. Os mercados davam sinais de saturação, a que se seguiam pressões de preços e de custos, num cenário de intensa competição. A insatisfação trabalhista desencadeava seguidas greves por majorações salariais, e essas, por sua vez, eram elementos adicionais a reduzir margens de lucros; caía o nível de investimentos. A eficiência marginal do capital se acercava de seu ponto de inflexão. Em especial, o mercado internacional de matérias-primas e insumos era alvo de uma forte pressão especulativa que ameaçava provocar uma explosão de preços. Porém, como se não bastassem tais elementos perturbadores, outras tensões mais profundas corroíam a aparente prosperidade geral e questionavam o american way of life, paradigma da febre consumista do período (Hobsbawm, 1995).

\section{Turbulência política e cultural}

A abundância material de um modelo produtivo que tinha nos bens duráveis de consumo seu sustentáculo, no petróleo e seus derivados sua base energética, e no mercado de massas sua justificativa político-ideológica, ocultava recônditas cicatrizes que o passar dos anos e a exposição das engrenagens de funcionamento do sistema - possibilitada pelo acirramento de contradições latentes não deixariam de revelar.

Resistências insuspeitadas anos antes afloravam. Projetos de vida antagônicos entravam em choque. Havia uma insatisfação crescente no ar. Jovens se insubordinavam com o padrão de vida imposto pelos pais. Velhas ideias eram contestadas. A arte combatia concepções obsoletas e inaugurava novas linguagens. 0 pós-modernismo começava a substituir as macrovisões modernistas pela glorificação do efêmero, do fragmentário, do superficial, da ausência de sentido. Uma sociedade alternativa era a proposta do movimento hippie. Aumentava a consciência da iniquidade internacional e da hipocrisia de hábitos e discursos. As práticas militaristas, o vazio de existências preenchidas com abundância bens materiais de consumo, a alienação da propaganda e da massificação, o racismo, o machismo e o preconceito, a dilapidação dos recursos naturais, a anacrônica moralidade sexual, todas essas características se revelavam como a outra face da moeda da prosperidade burguesa e da dominação americana (Harvey, 1996; Jameson, 1991).

Como decorrência dessa nova situação, assistiu-se, ao longo das décadas de 1960 e 1970, a uma miríade de movimentos de contestação antissistêmicos em todo o mundo, que atravessavam um amplo espectro político e ideológico, com fortes conotações culturais. Referimo-nos a revoltas estudantis em praticamente todas as grandes cidades do mundo rico (dos quais a revolta de 1968 em Paris é a mais impressionante expressão), mas também em muitas metrópoles do terceiro mundo; massivas mobilizações pacifistas e de desobediência civil (contra a convocação à guerra do Vietnã nos Estados Unidos, por exemplo). De igual 
modo, governos nacionalistas ou reformistas, de forte conteúdo anti-imperialista, bem como movimentos guerrilheiros de esquerda que algumas vezes chegavam (ou ameaçavam chegar) ao poder representavam outros elementos de instabilidade a até então aparentemente inabalável ordem mundial do pós-guerra.

Tampouco o bloco socialista escapava a tais perturbações. Contradições subjacentes, por um lado oriundas, em boa medida, das vicissitudes da revolução ter ocorrido em um país pobre e semidestruído pela guerra e, logo a seguir à revolução, pela guerra civil e a agressão externa - a Rússia de 1917 -, e, por outro lado, contradições provenientes da forma como o bloco socialista após a II Grande Guerra constituiu-se, quase sempre como produto da ocupação militar soviética, vieram à tona. Após atingir um determinado patamar de desenvolvimento, o sistema econômico revelou-se incapaz de elevar a produtividade e escapar à tendência dos rendimentos decrescentes. A qualidade de vida da população estagnou, quando não regrediu. Insatisfações populares latentes irromperam aqui e ali, e a mais importante delas, a tentativa de democratizar o regime na Tcheco-Eslováquia que ficou conhecida como a "Primavera de Praga", provocou a intervenção violenta das forças armadas da URSS e do Pacto de Varsóvia na capital tcheca em agosto de 1968.

Por último, mas não menos importante, a sucessão de tensões que se precipitaram a partir de meados dos anos 1960 foi completada com a decadência norte-americana, expressa por um conjunto de acontecimentos e indicadores, como veremos a seguir.
Hegemonia dos Estados Unidos em cheque

Os Estados Unidos, de principal credor global ao final da II Guerra, havia se transformado, pouco mais de vinte anos depois, no principal devedor mundial. As maciças exportações de capital americano, vinculadas a programas públicos de ajuda e inversões militares, bem como as pesadas injeções de recursos das em presas multinacionais norte-americanas no mundo, respondem por esse resultado. Mas os desdobramentos das ações derivadas da supremacia incontestável dos Estados Unidos no mundo capitalista e a idiossincrasia própria dos yankees e do "destino manifesto" - isto é, a crença na suposta inevitabilidade da liderança dos americanos na defesa do mundo "livre", da democracia e dos valores ocidentais - foram mais profundos ainda, e conduziam a superpotência à decadência e à perda de prestígio internacional. Ambas pareciam, no curso daqueles anos, irreversíveis. Serviam para comprová-las a perda de competitividade dos produtos americanos, o déficit comercial e o de pagamentos, a defasagem tecnológica, a pressão sobre o dólar - fenômenos que assumiram sua plena expressão na década seguinte e que abordaremos a seguir - e, sobretudo, os agudos desafios políticos e militares que desafiavam a superpotência norte-americana.

Em todas as regiões e continentes, governos, movimentos sociais, insurreições armadas, novos alinhamentos políticos e formulações ideológicas confrontavam os interesses dos Estados Unidos. Na América Latina, desde a Revolução Cubana, na virada das décadas de 
1950 e 1960, se multiplicaram, ao longo dos 1960 e na década seguinte, governos reformistas e esquerdistas que flertavam com ideias socialistas e estabeleceram, amiúde, relações de cooperação com a URSS. Esses governos foram pródigos em nacionalizar empresas de propriedade norte-americana ou tentar impor limites à sua atuação. As reformas incluíam ou projetavam - aumento da presença do Estado na economia e alterações perigosas para os setores dominantes internos na correlação de forças, em benefício de interesses populares. Para agravar o cenário de hostilidades, entre golpes militares de direita patrocinados pelos Estados Unidos e as reações da esquerda, ocorrem a vitória sandinista na Nicarágua (1979) e a deposição da ditadura Somoza, abertamente apoiada pelos americanos. Havia a ameaça do surgimento de uma segunda Cuba na América Central, tradicional "quintal" dos norte-americanos. Por último, um acontecimento de grande relevância política na América Central, ocorrido à época da revolução nicaraguense - embora não se tratasse de um episódio militar -, foram os tratados celebrados em 1977 entre o presidente dos Estados Unidos à época, Jimmy Carter, e o presidente do Panamá, Omar Torrijos, de devolução do Canal do Panamá e da região limítrofe de Bilbao à plena soberania panamenha. Essa região estratégica do istmo centro-americano constituiu, ao longo de um século, propriedade extraterritorial norte-americana em pleno espaço panamenho, de típico caráter neocolonial (assim como a Base de Guantánamo até hoje o é em território cubano). A retomada do Canal pelo Panamá, concluída em 1999, foi interpretada pelos conservadores dos Estados Unidos como mais uma derrota americana, inaceitável diante das doutrinas de supremacia militar e estratégica vigente e como mais uma peça perdida no conflito com os soviéticos.

Na África, após a Revolução de Abril de 1974 em Portugal, o processo rápido de descolonização que se precipitou transformou todas as ex-colônias lusitanas em países independentes autointitulados socialistas, com explícito apoio soviético. Na Etiópia, por sua vez, um governo de inspiração marxista se instalou à época, ao mesmo tempo em que muitas outras nações africanas estabeleciam relações amistosas com o bloco socialista. Por outro lado, movimentos guerrilheiros no território africano contavam com declarado apoio cubano ou professavam ideais maoístas.

Na Ásia, a derrota militar no Vietnã (abril de 1975) foi catastrófica para os Estados Unidos, depois de anos de vultosos recursos investidos e milhões de homens mobilizados, 0 prestígio da superpotência - que se revelou vulnerável ante um adversário tremendamente inferior em efetivos e material bélico - despencou e provocou na seqüência a queda de regimes pró-americanos no Laos e no Camboja, que instalaram ali governos pró-soviéticos. Mesmo com a reaproximação da China com os Estados Unidos a partir do encontro de Nixon e Mao em 1972, a situação, do ponto de vista dos interesses americanos na Ásia, era mais que preocupante, ante o momentâneo avanço das posições soviéticas.

Por fim, em se tratando da convulsiva zona do Oriente Médio, o contexto não era mais favorável. Muito ao contrário. 0 sistemático apoio norte-americano a Israel havia lhe granjeado uma contumaz antipatia no seio das populações árabes, refletida em grande parte de seus governos. Hostil à causa palestina, os 
Estados Unidos sofreram as consequências de seu posicionamento. Mais uma vez, os soviéticos se beneficiaram do desgaste americano junto aos povos árabes. Novos alinhamentos foram definidos na região, e os Estados Unidos se viram encurralados diplomaticamente. A situação só piorou com a queda do Xá Reza Pahlevi (1919-1980) no Irã, em 1979. Maior aliado dos Estados Unidos no Oriente Médio, o Irã se transformou subitamente no seu principal inimigo na região.

O Movimento dos Países Não Alinhados, criado na Conferência de Bandung, na Indonésia, em 1955, que chegou a congregar mais de uma centena de nações, também se constituiu, na prática, um poderoso instrumento internacional de pressão contra os interesses norte-americanos.

Em suma, a despeito das dificuldades que o bloco socialista capitaneado pela URSS enfrentava, poderia parecer, aos olhos do observador menos atento, que a União Soviética, na disputa da guerra fria, estava avançando posições sobre seu oponente direto. Na verdade, tanto os Estados Unidos se deparavam com sérios desafios à continuidade de sua supremacia nos marcos políticos, econômicos e institucionais com os quais até então era exercida, quanto era certo que o mundo socialista aliado à URSS vivia seu "canto do cisne", parcialmente ocultado por estatísticas econômicas tergiversadoras de uma realidade de baixa produtividade, atraso tecnológico e desperdício de recursos escassos, e por triunfos efêmeros no conflito ideológico com os países capitalistas, que as profundas mudanças na economia global solaparam de forma definitiva.

\section{Crise dos anos 1970: início das transformações estruturais}

\section{Choques do petróleo e elevação do preço das matérias primas}

Quando a década de 1970 se inicia, as tensões da economia mundial se amplificam, repercutindo sobre o preço das matérias-primas e, principalmente, sobre o petróleo, insumo energético que constituía o próprio paradigma da civilização do século XX. Nos Estados Unidos, as condições da crise latente convergiam de maneira particularmente explosiva, como não poderia deixar de ser, por sua condição de país-líder da economia global e expressão maior da era do petróleo barato, da dependência do automóvel e dos bens de consumo durável fabricados em boa medida com produtos derivados do petróleo, como o plástico.

Sublinhamos, primeiramente, a perda de competitividade dos produtos norte-americanos no mercado global de bens e serviços, reflexo do avanço da tecnologia produtiva e das inovações na Alemanha e no Japão. Por seu turno, as enormes proporções da exportação de capital dos Estados Unidos a partir do pós-guerra, importando em crescentes montantes de recursos a título de empréstimos e gastos militares, e o elevado grau de internacionalização das corporações americanas, tornaram os Estados Unidos, de principal credor mundial no pós-guerra, o principal devedor mundial a partir da década de 1970; o gigantesco déficit comercial e de pagamentos é resultante dessa 
inversão de tendências da posição americana na economia global. Em terceiro lugar, na medida em que o valor da moeda de cada país reflete o estado da economia nacional, o dólar se desvaloriza continuamente ao logo da década de 1970, levando inclusive à perspectiva de sua substituição como padrão monetário universal. Por fim, o acentuado declínio da hegemonia norte-americana, ameaçada em todas as frentes - militar, política, econômica, tecnológica e financeira (Wallerstein, 2001).

Desde os anos 1970 - quando os países ricos descobrem a gravidade de sua dependência energética de abastecedores externos - começa um ciclo de mudanças associadas ao profundo impacto acarretado pela quadruplicação do preço do petróleo. A Organização dos Países Exportadores de Petróleo - OPEP -, criada em 1960 a fim de defender os países produtores das manobras com preços praticadas pelo cartel das multinacionais controladoras do comércio de petróleo, se apercebeu da oportunidade criada pelo contexto de explosão da demanda, a dependência do aparato produtivo global em relação aos hidrocarbonetos, e a virtualidade concreta do controle da oferta. Nesse sentido, é válido interpretar os choques do petróleo da década de 1970 (1973 e 1979) não como causa específica, mas, a um só tempo, como resultantes e fatores detonadores do conjunto de tensões acumuladas nos anos anteriores por um modelo econômico consumista, fundado em grande medida no uso intensivo de uma fonte de energia não renovável, cujos preços, até então, haviam sido mantidos artificialmente baixos pela manipulação de companhias monopolistas multinacionais de origem norte-americana e europeia, controladoras da produção e distribuição de petróleo e seus derivados (Pipitone, 2003).

Isso mudou radicalmente a partir da ação determinada da OPEP. Transformam-se em poucos anos esquemas e práticas competitivas, custosas tecnologias revelam-se bruscamente obsoletas. A necessidade de reduzir custos internos para enfrentar a situação de preços internacionais em alta vertiginosa se fez inadiável. No contexto das grandes regiões do mundo, é a Europa que experimenta maior turbulência pelo choque energético. Desde então se reforçará a demanda por novos bens capazes de reduzir custos (automatização, computadores, reengenharia da produção) e permitir a reconstrução de posições competitivas debilitadas ou ameaçadas. É nessa situação que a aceleração econômica se interrompe, convertendo uma crise estrutural de crescimento em uma recessão que abrirá um longo período recessivo, primeiro nos países ricos, depois no conjunto da economia global.

A crise econômica dos anos 70 reavivou o debate sobre as crises capitalistas entre os autores comprometidos com a tradição marxista. Neste momento começa a se desenvolver a Escola Francesa da Regulação, que parte da análise feita por Marx do modo de produção capitalista, e busca articular as questões da acumulação capitalista com as leis de concorrência. Assim, vão conceituar o fordismo como o modo de desenvolvimento que caracterizou o crescimento econômico capitalista após a II Guerra. A crise dos anos 1970 seria a crise desse modo de regulação entre capital e trabalho, com a mediação do Estado (Bocchi, 2000). 
Fim dos acordos de Bretton Woods: liquidez internacional descontrolada

Com o choque do petróleo em 1973, rompe-se o precário equilíbrio que ainda sustentava o ciclo virtuoso do pós-guerra. Inaugura-se um período de fortes restrições macroeconômicas no núcleo industrializado do capitalismo. Os estados veem sua receita cair drasticamente, a inflação se acelera, declina subitamente o nível de atividade. 0 desemprego aumenta as prestações sociais do Estado e os gastos com assistência e previdência pública. Isto é, ao mesmo tempo em que se reduz a arrecadação, aumentam as despesas governamentais. Sem esquecer que a corrida armamentista continuava demandando enormes somas de recursos públicos. A crise fiscal do Estado vai, doravante, minar a equação keynesiana que sustentou 0 crescimento do pós-guerra, alavancado pelo dispêndio público, e embasar as críticas neoliberais à atuação do Estado na economia.

As fases de contração do nível de atividade usualmente provocam excesso de liquidez. 0 capital tem mais dificuldade em encontrar oportunidades lucrativas para investir seus excedentes. Nos anos 1970, esse fenômeno, oriundo da queda do produto interno das nações industrializadas, foi significativamente potencializado pelo excesso de recursos carreados para os países produtores de petróleo - na maioria países árabes -, gerando uma extraordinária liquidez proveniente da circulação internacional dos chamados petrodólares.

No contexto de desvalorização do dólar, flutuação do valor das moedas e aumento da especulação com ativos, a manutenção da paridade cambial, que era a base da estabilidade financeira do pós-guerra, ficou insustentável.
A crise que conduziu ao fim do regime monetário de Bretton Woods resulta da combinação de dois fatores. Em primeiro lugar, o forte aumento da circulação de dólares devido aos sucessivos déficits do balanço de pagamentos dos Estados Unidos. Em segundo lugar, o crescimento exponencial do mercado de eurodólares (alimentado pelos petrodólares) a partir da segunda metade da década anterior, que leva à pressão da demanda global por ouro e ao aumento desordenado da liquidez internacional fora do controle do Federal Reserve - FED, o Banco Central americano. Esses dois acontecimentos criaram um excedente de dólares incompatível com o ouro disponibilizado como lastro para o dólar. Reflexo das enormes dificuldades estruturais dos Estados Unidos para conduzir sua liderança nos marcos até então fixados, o presidente Richard Nixon (1913-1994), em agosto de 1971, aboliu unilateralmente 0 acordo de conversibilidade do dólar em ouro. As moedas, a partir daí, passaram a flutuar livremente, acrescentando um novo fator de instabilidade a uma conjuntura cheia de incertezas (Silver e Arrighi, 2014).

Surge, então, um novo padrão monetário, que vai configurar as relações financeiras globais pelas décadas seguintes: o padrão dólar flexível. Ele demarca o início da chamada financeirização da economia global, ou seja, a volta, sob novos contornos, da grande finança ao centro do poder, numa espécie de revanche contra aqueles que lutaram contra a liberdade dos capitais na era pós-guerra (Chesnais, 2005; Furtado, 1999).

No entanto, a revanche da grande finança não parava aí. Com liquidez de sobra, os recursos excedentes buscaram praças financeiras alternativas onde operar, que lhes garantissem 
a máxima flexibilidade e rentabilidade, livre das amarras e do controle dos bancos centrais típicos dos esquemas oriundos de Bretton Woods. Surgem desse contexto e se fortalecem sobremaneira nos anos 1960 os mercados off-shore. Liberados das imposições anteriores, essas novas praças financeiras absorveram o mercado de eurodólares e os direcionaram para aplicação de recursos naquelas regiões e projetos cujas perspectivas de retorno fossem maiores, incorporando nessa estratégia o conteúdo especulativo e as elevadas margens de risco características das operações guiadas exclusivamente pelos interesses da grande finança.

Dessa forma, os Estados Unidos, apesar de acossados em várias frentes, valeram-se de sua condição hegemônica para defender seus interesses de forma unilateral, comportamento esse usual dos norte-americanos, que sempre se pautaram, sobretudo (e não raro exclusivamente), em si mesmos na defesa da ordem capitalista (Tavares e Fiori, 1997). 0 rompimento da paridade com o ouro levou a sucessivas desvalorizações do dólar ao longo da década de 1970 - sinais eloquentes das dificuldades americanas já relatadas -, mas criou, por outro lado, as condições para sua fulminante reação econômica, política, militar e ideológica depois da chegada de Ronald Reagan ao poder em 1979, que reverteu as regras do jogo global a partir, exatamente, da política do dólar forte (Tavares e Fiori, 1997).

A necessidade de encontrar aplicações rentáveis a essa massa de liquidez oriunda, tanto da recessão nos países ricos, quanto do excedente do petróleo, leva o mercado interbancário privado a investir pesadamente em um grupo selecionado de países do terceiro mundo e nos países socialistas, inversões essas usualmente relacionadas a ambiciosos projetos de desenvolvimento energético e de infraestrutura para exportação. Dinheiro fácil e abundante, com juros baixos, era um poderoso atrativo para multiplicar a dívida externa desse conjunto heterogêneo de tomadores de recursos. Registre-se aqui que o Brasil, à época da implantação do II Plano Nacional de Desenvolvimento - PND (1974-1979) -, foi um dos maiores receptores de crédito externo. A armadilha embutida nesses empréstimos eram os juros flutuantes, isto é, as reduzidas taxas poderiam ser revertidas a qualquer momento, obedecendo a uma decisão dos prestamistas.

\section{9: reação dos Estados Unidos}

A ascensão de Ronald Reagan (1911-2004) ao poder em 1979 inverte a correlação de forças no âmbito da classe dominante nos Estados Unidos. Predominam a partir de então os setores mais conservadores e agressivos, com fortes vínculos com o complexo militar-industrial interno. Uma estratégia de contra-ofensiva política, ideológica e militar é posta em prática, com ousadia e determinação. Coadjuvados com o mesmo grau de conservadorismo e agressividade pela aliada Margareth Thatcher (primeira ministra britânica de 1979 a 1990) na Inglaterra, os americanos implantam um ambicioso programa de defesa espacial (o "Guerra nas Estrelas"), revertem a política negociadora dos conflitos que caracterizou o governo anterior de Jimmy Carter - invadindo Panamá e Granada, para destituir governos hostis aos Estados Unidos -, adotam posições intransigentes no Oriente Médio e no Afeganistão, e reforçam sua rede de bases militares em todo o planeta. 
Nesse plano político-militar, basta dizer que 0 programa Guerra nas Estrelas, pelos elevados custos envolvidos, quebrou a já debilitada economia soviética, pela impraticabilidade dos russos suportarem a atualização militar no nível e intensidade que o desafio americano implicava.

$\mathrm{Na}$ esfera financeira, os Estados Unidos fizeram valer, a um só tempo, a propriedade da moeda universal e a liberdade de fixar seu valor. A liquidez global volta a ser absorvida pelos títulos do tesouro americano, único porto seguro ante as incertezas reinantes. 0 dólar se reafirmou de maneira implacável, ancorado no poderio político e militar da superpotência. 0 choque de juros imposto pela Reserva Federal norte-americana em setembro de 1979 representou uma aposta arrojada na recuperação da supremacia americana por intermédio da política do "dólar forte", como uma imposição, mais uma vez unilateral, ao resto do mundo. Uma aposta - que se revelou bem-sucedida - na retomada da hegemonia global norte-americana.

0 efeito da subida abrupta da taxa de juros e da consequente valorização do dólar foi dramático no mundo. A valorização da moeda americana reforçou sua função como meio de pagamento universal, unidade de conta nos contratos e preços dos mercados internacionais e principal reserva de valor. Às desvalorizações das outras moedas se somou um cenário de estagflação, especulação com ativos, contração da liquidez, estrangulamento fiscal do Estado e crise dos devedores, atingido especialmente os países que contraíram pesados empréstimos internacionais na década anterior.

\section{Anos 1980/90: globalização financeira e reestruturação produtiva}

\section{Ajustes neoliberais}

A radical reversão das regras do jogo financeiro no final dos anos 1970 provocou profundas consequências no quadro geoeconômico global. No terceiro mundo, a dívida externa experimentou um salto espetacular, impulsionado pela elevação dos seus encargos financeiros, o chamado serviço da dívida. A inadimplência, a ameaça de moratória e a incapacidade de prover serviços básicos às suas populações tornavam-se perspectivas reais na vida cotidiana das nações. Planos de desenvolvimento tiveram que ser repentinamente abandonados. Sobraram as contas a pagar. Ficou como saldo um cenário de recessão e desemprego. Planos de austeridade fiscal e severa contração do nível de atividade, acrescidos da prioridade às exportações, foram impostos pelos credores a fim de gerar superávits na balança de pagamentos capazes de lastrear o pagamento das prestações da dívida.

No lado socialista, a crise que já se anunciava há vários anos se escancarou e resultou no colapso da URSS e de todos os seus satélites. Aos fatores especificamente políticos da crise se somavam a gravidade do quadro econômico e financeiro, tornado explosivo pela alta dos juros e o aumento intolerável dos gastos militares. No nível sistêmico, os incentivos 
para a inovação e a produtividade haviam sido eliminados pela centralização burocrático-autoritária, criando imensos desníveis setoriais, por erros de planificação e vícios de execução. 0 insatisfatório atendimento das demandas e a má qualidade (somado à escassez) dos produtos alimentaram um regime de duplicidade - a ficção dos números e dos discursos e a realidade - e de mentiras oficializadas. 0 fim de uma era afigurava-se irreversível. Contudo, não se esperava que a retirada estratégica fosse tão desmoralizante, nem que os descomunais esforços de mais de meio século viessem a ser reduzidos a pó. Chegava ao fim uma experiência original que, ao longo de mais de meio século, transformou completamente todos os aspectos da vida de uma sociedade, independentemente de seus vícios de origem e de execução. Foi um esforço sem paralelo histórico, nos seus objetivos, meios utilizados e sofrimentos causados. 0 desarmamento unilateral da URSS na década de 1980, o fracasso da perestroika e da glasnost, a autodissolução do Partido Comunista e da própria União Soviética, bem como do conjunto do bloco socialista a ela associado expressaram, ao fim e ao cabo, a falência de um modelo de transição pós-capitalista.

Desse modo, as mudanças ocorridas na economia também acarretaram radicais realinhamentos geopolíticos no planeta. 0 colapso do bloco socialista liderado pela URSS, que se consumaria até o final da década de 1980 (a queda do Muro de Berlim ocorreu em 9 de novembro de 1989), aliado ao desmantelamento das economias do terceiro mundo, assoladas pela crise da dívida, levou certos analistas a decretar o triunfo definitivo das economias de mercado e decretar o "fim da história", pelo menos da maneira como até então a tínhamos conhecido, marcada pela luta de classes e, ao longo da quase totalidade do século $\mathrm{XX}$, pelo conflito ideológico entre duas visões de mundo antagônicas (Anderson, 1992).

Adentra-se no período dominado por ideias e práticas neoliberais. Embora seja um termo cunhado pelos seus críticos e não pelos adeptos dessas concepções, a doutrina neoliberal é usualmente associada à defesa do livre mercado e ao combate ao intervencionismo estatal. Nesse sentido, constitui tanto uma reação aos postulados marxistas de política econômica, quanto às concepções keynesianas (Pipitone, 2003).

A aplicação do receituário neoliberal, promovido pelo núcleo dos países ricos encabeçados pelos Estados Unidos e endossado pelo Banco Mundial e o FMI, produziu um efeito perverso sobre o mercado de trabalho, ao destruir milhões de postos de trabalho assalariado e substituí-los pelo trabalho precário, terceirizado, gerando um saldo líquido de aumento do desemprego e do subemprego. Seu viés político conservador também ficou evidenciado pelo ataque às conquistas históricas dos trabalhadores, privatizando serviços públicos, flexibilizando direitos trabalhistas, pulverizando o movimento sindical e revertendo avanços consolidados pelo Estado do bem-estar social.

Os ajustes ortodoxos, de inspiração neoliberal, monetarista, foram aplicados em muitos países do mundo, em especial na América Latina e nos países pós-socialistas da Europa oriental. Tais políticas visaram garantir as condições de operação do mercado livre para os fluxos de capital, principalmente externo, e propiciar os meios de pagamento aos credores da dívida externa, por meio de políticas contracionistas de forte restrição aos gastos 
públicos. Em suma, abertura, individualismo, desregulamentação e privatização constituíram o arcabouço programático por trás das políticas de austeridade monetária e arrocho fiscal (Anderson, 1992).

0 capital financeiro foi o principal beneficiário desse conjunto de medidas, pois, acoplado aos avanços tecnológicos que se aceleraram nesses anos e ao virtual desaparecimento das restrições ao seu livre movimento, estabeleceu as bases de uma globalização caracterizada precisamente por seu protagonismo. A multiplicidade de inovações e novos produtos permitiram a securitização das dívidas. Novos agentes foram incorporados ao processo, como os fundos de pensão. 0 "cassino global" invadiu todas as artérias do sistema. É a chamada financeirização da economia, isto é, as finanças no comando do desempenho da economia real, aquela relacionada à produção de bens e serviços de natureza industrial. Instala-se uma lógica diferente, de natureza especulativa, cujo horizonte temporal é o curto prazo. A própria urbanização - sob o comando dos incorporadores imobiliários e seus parceiros públicos e privados - se converte em campo privilegiado da inversão financeira e da absorção de excedentes de capital. Nessa economia de fluxos, predominam o efêmero, o contingente, a espetacularização do consumo, a conversão de todas as dimensões da vida ao critério mercantil (Harvey, 2006).

A repentina alteração da política monetária americana em 1979 recentralizou nos Estados Unidos o dinheiro mundial sob controle privado e caracterizou-se por um novo salto, sem precedentes, na concentração da riqueza. Valorizaram-se as ações e aumentou o consumo das famílias nos Estados Unidos, o que, sob finanças desreguladas, conduziu, anos depois, a bolhas especulativas e crises nos mercados acionários e imobiliários. Já a Europa sepultou qualquer veleidade de nacionalismo econômico e aplicou políticas ortodoxas e profundamente recessivas. Essa inversão de sinais provocou a transferência líquida de recursos reais da periferia para o centro do sistema, ao longo da década de 1980, revertendo drasticamente 0 fluxo de empréstimos internacionais da década anterior. A América Latina - em especial, 0 Brasil - constituiu um exemplo conspícuo dessa sangria de recursos. Pode-se afirmar, assim, que os países pobres financiaram, em grande medida, o processo de recuperação dos países ricos e a retomada da hegemonia global norte-americana.

Por seu turno, a abertura financeira imposta ao Japão na mesma década - seguida depois pelos "tigres" asiáticos -, a vulnerabilidade externa dos capitais especulativos e a valorização do iene (em 1985) provocaram uma sucessão de crises na região. Os Estados Unidos, mais uma vez, exercendo sua capacidade de determinação das taxas de câmbio internacionais, recuperaram a posição de comando que, aparentemente, o Japão estava Ihe tomando. É preciso ressaltar, no entanto, que a China saiu ilesa dessa turbulência, e até se beneficiou dos problemas vividos pelo Japão, substituindo-o a partir de então como o núcleo dinâmico da economia de subcontratação asiática. 0 controle de capitais, entre outros aspectos de seu peculiar processo de abertura econômica e modernização planejada seguindo em direção inversa ao preconizado pelo receituário neoliberal - Ihe permitiu crescimento sustentado e profunda reestruturação produtiva (Arrighi, 2008). 
As crises financeiras multiplicaram-se desde os anos 1980. Sua natureza segue de perto a evolução da economia global, no rumo de uma crescente financeirização, cuja lógica do ganho imediato, do jogo e da especulação permeia a administração das corporações transnacionais e da gestão fazendária estatal. Em 1982, a moratória nos pagamentos aos credores externos inaugura mais de uma década de crises sucessivas relacionadas à expansão desmedida da dívida externa nos países que contraíram excessivos compromissos nos anos anteriores, de crédito farto e barato, principalmente na América Latina. 0 terrível desfecho da experiência de dolarização argentina, em 2001, fecha esse ciclo. A quebra das gigantes norte-americanas do sistema de poupança e empréstimos, entre 1989 e 1991, abre um período no qual as crises mudam de figura e se relacionam diretamente com o movimento frenético, "irracional" dos mercados envolvidos em apostas especulativas com ações, divisas e imóveis. Os efeitos da explosão dessas bolhas especulativas foram muitas vezes dramáticos, provocando falências, desemprego, dilapidação de recursos patrimoniais e socialização das perdas, com o Estado e o contribuinte arcando com a cobertura de passivos e outros vultosos prejuízos. Exemplos desse último tipo de crise são aquelas ocorridas no sudeste asiático em 1997, na Rússia em 1998, nos Estados Unidos, com o desabamento das ações das empresas de internet (a bolha dot. com) em 2001 e, intercalada com sucessivos abalos no mercado acionário e imobiliário em diversos países - agravado pelos efeitos do atentado terrorista de 11 de setembro de 2001 em Nova York -, a quebra do mercado de hipotecas nos Estados Unidos em 2007, que deflagrou efeitos contracionistas globais de longa duração.

\section{Tecnologia e indústria}

A fase de predomínio financeiro e da ideologia do livre mercado deixou um legado de baixos níveis de crescimento econômico - com a exceção dos Estados Unidos nas décadas de 1980 e 1990 -, desemprego estrutural persistente, desqualificação da ação do Estado, ruptura dos mecanismos de regulação pública, sucateamento de equipamentos e políticas sociais, privatização de espaços públicos, ideologia consumista e a mercantilização total da vida coletiva, pautada pelo exacerbado individualismo. Porém, efeitos derivados do conteúdo político das medidas adotadas - sujeitos, portanto, a mudanças inesperadas em função da correlação de forças em distintos momentos históricos e espaços geográficos - não ocultam transformações de longa duração na vida econômica e social dos povos. 0 mundo mudou, e muito, desde aqueles anos. A ciência percorreu caminhos vertiginosos, e inovações impensadas há pouco tempo fazem parte, hoje, do cotidiano das populações de todo o mundo, e projetam evoluções ainda mais revolucionárias no futuro próximo. A pressão competitiva que se originou com a crise energética dos anos 1970 também trouxe consigo a necessidade de as empresas renovarem tecnologias de produção e de organização do trabalho, objetivando eficiência e redução de custos.

Ao lado do esforço de conter despesas, é preciso novamente enfatizar que uma transformação de grande alcance se avizinhava, afetando o próprio paradigma tecnológico 
dominante. A mudança da produção em massa, padronizada, para métodos produtivos flexíveis, incorporou novas tecnologias com base na microeletrônica e novos processos de gestão a denominada economia do conhecimento -, e fez da inovação permanente sua própria razão de ser. Por sua vez, a recomposição oligopólica, por meio de um vigoroso ciclo de fusões e aquisições, e de parcerias de toda ordem, levou à criação de "empresas-rede", cadeias de suprimentos e distribuição de alcance mundial, inaugurando a fase que alguns analistas (mormente os regulacionistas) chamam de "pós-fordista" de organização industrial. Tradicionais políticas de inspiração keynesiana de estímulo à demanda agregada perdem eficácia, formuladas a partir do referencial do Estado-nação. Como a técnica não está dissociada do padrão vigente de relações sociais num determinado tempo e lugar, essa profunda transformação científico-tecnológica está impregnada do espírito capitalista de rentabilidade a qualquer preço, e coube às corporações transnacionais, alicerçadas num extraordinário poder financeiro, a liderança desse processo. Na evolução dos acontecimentos, porém, empresas de distinto porte e regiões selecionadas em todo o planeta foram incorporadas ao movimento de acumulação de capitais.

Não obstante o super-dimensionamento do setor financeiro e o desemprego estrutural que o novo regime de acumulação provoca, é fundamental ressaltar que o capitalismo atual, na conformação que assumiu a partir do último quarto do século passado, garante sua dinâmica também em função da queda dos preços dos produtos globais, o que permite a absorção contínua de mercados até então à margem do consumo por falta de renda. A miniaturização, as novas tecnologias e o barateamento dos custos popularizaram em grande escala os bens da indústria eletrônica, por exemplo.

Cumpre adicionar que a interação da tecnologia informacional, a produção material e os novos modelos de gestão tornam obsoletas as divisões rígidas entre indústria e serviços, empresa industrial e empresa financeira, trabalho produtivo e trabalho improdutivo. 0 importante é a agregação de valor em cadeias produtivas que conjugam diferentes fases da elaboração de um bem econômico, como cidade e campo, fabricação material e serviços produtivos, espaços físicos e espaços digitais (Scott, 2012).

\section{Estados nacionais, urbanização e economia contemporânea}

Os fenômenos decorrentes da revolução científico-técnica e da globalização afetaram a capacidade de os estados nacionais exercerem as funções típicas da fase intervencionista do pós-guerra, e mesmo algumas das tradicionais (como saúde, educação, segurança, saneamento). Tal situação impôs alterações profundas na agenda pública, no seu escopo e na forma de financiamento de suas atividades. 0 tema do desenvolvimento, tão presente no debate teórico e nas políticas dos estados do terceiro mundo no pós-guerra, desaparece da agenda política. Fortemente vinculado a transformações estruturais da economia e a distribuição de renda, as estratégias desenvolvimentistas cedem espaço, quando muito, a abordagens quantitativistas do crescimento, na suposição de que o simples aumento do PIB conduziria ao bem-estar geral da coletividade. Num momento de transição 
e crise fiscal dos estados, saltam à vista os problemas de ineficiência de muitos serviços públicos, corrupção e burocratismo. Mas tudo isso não implica, no horizonte previsível e nos marcos do regime capitalista, a supressão, ou sequer a superação, dessas instituições vitais a gestão do sistema.

A moeda forte, as políticas industriais e tecnológicas e os mecanismos financeiros estratégicos são resultado da ação do respectivo Estado nacional, e não de sua omissão ou definhamento político.

Assim, a estabilidade na economia mundial só pode ser conquistada e mantida por meio do concurso decisivo dos estados nacionais, não só pela capacidade de regulação macroeconômica e do conflito social, mas principalmente por garantir legitimidade aos processos de gestão supra e subnacionais. É precisamente na articulação das diferentes escalas territoriais, entre o local e o global, que reside a possibilidade de governança internacional na direção do interesse coletivo, que tem na instância pública nacional, com a devida esfera de autonomia, o elo decisivo. Nesse contraditório mosaico, o Estado nacional não perdeu relevância, mas hoje ele compartilha seu poder com outros atores. A construção institucional desse complexo mundializado segue sendo um desafio em aberto, e os conflitos, derivados desse impasse, se multiplicam em todas as latitudes e longitudes do planeta (Chang, 2003; Brenner, 2004).

Como vimos, os anos 1980 inauguraram um conjunto de mudanças de grande repercussão na existência social. Alterações conjunturais, respostas momentâneas à crise, provocaram e se mesclaram a transformações estruturais, de maior fôlego, resultando desse complexo entrelaçado um mundo globalizado, cuja sociedade experimenta novas tecnologias de produção e de vida, diferentes perspectivas, novas formas de desigualdade, que se juntam às antigas e as reconfiguram. 0 espaço geográfico é palco dessas intensas mudanças. Nele se desenrolam os fenômenos da reestruturação produtiva que reagrupa recursos e população (Massey, 2005). A urbanização já concentra mais da metade da humanidade e dita o rumo e o ritmo dos hábitos e esperanças dos povos. Essa participação urbana no total da população mundial deve alcançar $70 \%$ ou mais em 2050 , com um incremento de 3,5 bilhões de pessoas em 2010 para 6,2 bilhões em 2050. Quase a totalidade desse crescimento vai ocorrer em megalópoles de países em desenvolvimento. Cidades nos países desenvolvidos adicionarão apenas 160 milhões de pessoas à sua população nesse período, enquanto as cidades dos países menos desenvolvidos deverão absorver cerca de 2,6 bilhões de habitantes, duplicando assim sua população urbana de 2,6 bilhões em 2010 (UNFPA, 2010).

A metrópole da atualidade pode ser definida como o entrecruzamento do espaço de lugares e do espaço de fluxos, o núcleo territorial a partir do qual as redes de conexões físicas e virtuais são produzidas e coordenadas. A cidade industrial-fordista se caracterizava pela separação de usos, bem delimitados em termos de sua função residencial (de luxo, classe média e popular), industrial, comercial, lazer e de serviços. 0 eixo era a indústria: a circulação, as moradias, os corredores de abastecimento e distribuição, tudo girava em torno desse núcleo estruturador do espaço urbano. Imperava o planejamento modernista, com seu traçado de grandes vias retas de traçado ortogonal ou 
radiocêntricas e a priorização do automóvel. A cidade de São Paulo é um perfeito exemplo disso, inclusive pelas distintas fases que a economia urbana foi passando no decorrer do século $\mathrm{XX}$, alterando, com as mudanças econômicas, 0 uso, a valorização e a decadência de diferentes regiões da cidade.

A emergência dos contornos da cidade "pós-moderna", na esteira da reestruturação produtiva e da globalização das décadas recentes, desenha outra morfologia urbana, superposta ao ambiente construído herdado pelas metrópoles. Novas centralidades projetam uma cidade dispersa e multicêntrica. 0 espraiamento urbano alarga as dimensões municipais para âmbitos regionais, além de responder às novas necessidades locacionais das empresas - fugindo do alto preço do solo nas áreas centrais da cidade - e aos requisitos residenciais dos grupos de maior poder aquisitivo - os condomínios fechados de luxo - e das camadas populares, expulsas para localizações cada vez mais distantes das áreas valorizadas pelo mercado. Dado o esperado declínio nas densidades urbanas, estima-se que as cidades necessitem do triplo de áreas urbanizáveis em 2050, em relação ao que atualmente é utilizado.

Por sua vez, as novas geografias da produção industrial apontam lugares abandonados pelas empresas cujas plantas se deslocaram para a região do entorno (como em São Paulo), alargando o raio de influência do núcleo da região urbana. Em um ou outro caso, o efeito sobre a morfologia do espaço metropolitano salta à vista, gerando profundas implicações socioterritoriais. E não apenas no aspecto econômico-produtivo, no que concerne aos fluxos de circulação de mercadorias. Referimo-nos às novas localizações residenciais, comerciais e dos serviços às famílias. Essas acabam por gerar cidades fragmentadas, dispersas, conjugando altas e baixas densidades construtivas, elevando o custo e precarizando a qualidade dos serviços públicos prestados à população, produzindo consequências ambientais deletérias. 0 predomínio do terciário avançado, convivendo com novas manifestações do terciário empobrecido, constitui denominador comum. Na verdade, a urbanização planetária, visualizada por Henri Lefebvre décadas atrás como uma possibilidade virtual, é hoje uma realidade em todo o mundo, capaz de explodir o próprio conceito de cidade como unidade territorialmente delimitada, definida sobretudo com critérios demográficos (Brenner, 2014)

Contudo, há mais: a reestruturação produtiva corresponde a um período de hegemonia do mercado e, no contexto neoliberal, à desqualificação do Estado como gestor da política urbana integrada, bem como à compressão do espaço pelo tempo, permitido pela tecnologia informacional. Uma crescente exclusão social é o resultado quase inevitável dos grandes projetos urbanos que se multiplicam em cidades de todo o mundo (Smith, 2008).

0 mercado de trabalho apresenta maior dispersão e polarização de rendimentos. Uma camada profissional de altos salários, vinculada às empresas de ponta, encontra sua contrapartida em segmentos de renda baixa, terceirizados, temporários, indiretamente ligados a essas mesmas empresas globalizadas, ou formando o vasto contingente de uma nova pobreza urbana, de certo modo uma novidade nas cidades dos países ricos, mas uma camada superposta aos excluídos tradicionais, nas metrópoles do terceiro mundo. Essa realidade se expressa geograficamente em territórios do crime, 
cidades de muros, bairros degradados, privatização do espaço público, áreas de valorização que concentram edifícios de última geração, lazer conspícuo, ostentação de riqueza; em suma, cidades que perdem rapidamente a capacidade da vida em comum, da interação em paz e harmonia social.

Nesse sentido, pode-se afirmar que a alta rentabilidade dos projetos imobiliários constitui forte atrativo para inversões financeiras e investimentos estrangeiros diretos. As cidades competem entre si por esse tipo de inversão. $A$ diminuição do papel do Estado e do interesse público eleva a critério central - quando não exclusivo - da viabilidade das aplicações imobiliárias de capital a mais-valia (valorização) fundiária, o verdadeiro parâmetro urbanístico na construção do espaço urbano da atualidade.

Ademais, os capitalistas estão sempre produzindo excedentes financeiros, os quais necessitam, por força da competição, encontrar saídas para sua absorção na forma de investimentos lucrativos. 0 problema é que essa expansão ocorre em ritmo composto, a uma taxa aproximada de 3\% ao ano. Então se trata de encontrar aplicação rentável para massas crescentes de recursos, levando investidores a exercitar de forma frenética seus poderes de "destruição criativa" no sentido de sempre alavancar novas oportunidades de investimento (Harvey, 2011).

Isso envolve necessariamente os espaços geográficos e, nesses, a urbanização ocupa lugar proeminente. Novos espaços e relações espaciais são produzidos para dar vazão aos imperativos da acumulação de capital. Grandes projetos de requalificação urbana e megaeventos esportivos e culturais servem a esses propósitos. Os proprietários do solo e a coalizão de interesses que se forma em torno dos investimentos imobiliários (financistas, incorporadores, políticos, empresários da construção) alargam seu poder de classe e ditam os rumos do crescimento urbano. Ao mesmo tempo, o artificialismo da demanda inchada e da especulação com os preços provoca crises de superacumulação, endividamento e um espectro de inadimplências atrás de si. 0 capitalismo rentista cobra seu preço. A crise do subprime nos Estados Unidos, iniciada em 2007, é a mais recente e grave dessas manifestações de irracionalismo dos mercados, conduzidas em benefício da plutocracia dirigente.

As metrópoles globais materializam os atributos da economia contemporânea, e sintetizam suas contradições. Isso porque, se os desdobramentos dos atuais avanços tecnológicos viabilizam a descentralização da produção industrial, eles reforçam, ao mesmo tempo, a necessidade de integração dessa rede de unidades produtivas espacialmente dispersas e, com ela, os requerimentos de uma coordenação centralizada dessa rede. Da crescente complexidade dessa tarefa de dirigir unidades produtivas localizadas em diferentes contextos sociais e institucionais, em países com níveis de desenvolvimento e contextos históricos tão desiguais, decorre a necessidade de subcontratar os serviços legais, contábeis, administrativos, mercadológicos, de gestão de pessoas, entre outros, os quais, até então, estavam diretamente integrados à própria estrutura corporativa. Tais firmas de serviços produtivos e financeiros são mais tecnicamente exigidas quanto mais as empresas contratantes estejam submetidas a pressões competitivas em mercados globais, o que requer decisões rápidas e precisas em contextos voláteis. Para esses 
serviços especializados, as economias de aglomeração propiciadas pelos grandes centros urbanos são decisivas, de fato insubstituíveis: só esse ambiente lhes propicia talentos, intercâmbios pessoais diretos, instituições, permanente produção de informação, núcleos de poder governamental, entretenimento qualificado, centros de pesquisa, riqueza cultural, mercados de alta capacidade aquisitiva. Tais são os atributos das denominadas "cidades globais", que concentram ainda a contrapartida dessa modernidade, qual seja, os trabalhos terceirizados, mal pagos, e a exclusão social em larga escala. Essa centralização espacial das decisões é o inevitável corolário do modelo econômico vigente, concentrador de renda e riqueza (Sassen, 2001; 2007).

Em resumo, as metrópoles contemporâneas são poderosos entroncamentos de redes múltiplas, policêntricas, de caráter difuso, articuladas e integradas ao redor de certos polos dominantes. Contudo, a direção central do movimento de urbanização é, na atualidade, claramente hegemonizada pelo setor financeiro e as atividades a ele agregadas no conjunto do sistema econômico. Fenômeno esse, por sua vez, correlacionado à desregulação geral, concentração da renda e consumo de luxo que lhe é inerente, bem como à informalidade e precariedade das atividades produtivas de baixo valor agregado. Trata-se do conjunto de atividades de gestão do capital, que envolve tarefas materiais e simbólicas, cuja produção e direção estão localizadas nas grandes cidades do mundo.

\section{Século XXI: a era da incerteza}

A virada do novo milênio constituiu o momento simbólico de se efetuar um breve balanço histórico dos avanços, retrocessos e desafios pendentes na jornada humana pelo planeta Terra. 0 século $X X$ iniciou-se num cenário de perturbações, conflitos e transição hegemônica. Uma grande transformação econômica se processava. A urbanização em larga escala impunha novas pautas ao sistema produtivo e ao comportamento social. Uma mudança institucional começava a se tornar imperativa, sem que seus contornos se delineassem com precisão. A cultura se massificava, avançavam as conquistas científicas e sua conversão em tecnologia. 0 despontar do século XX anunciava uma nova era, cujo nascimento foi doloroso: a belle époque no final do século XIX prefigurava uma crise de grandes proporções. Mas a utopia constituía projetos de vida em permanente elaboração, defendidos com paixão, que mobilizavam milhões de pessoas em todo o mundo (Santos, 2001).

0 início do terceiro milênio também encontra o mundo transfigurado por crises, radicais mudanças tecnológicas, crônica instabilidade, conflitos e dramas sociais carentes de solução - depois de tantos experimentos, muitos deles traumáticos, ao longo do século anterior. Foram cem anos de intensas transformações. Se muitos dos problemas seculares (ou milenares) da humanidade não foram resolvidos, e outros mais foram agravados (caso da desigualdade social e dos danos ambientais), fatos 
positivos ocorreram, em se tratando de saúde, educação e acesso da população a inovações tecnológicas. A massificação do consumo de computadores e de aparelhos de telecomunicação abriu possibilidades inéditas de democratização da informação. 0 controle da informação desencadeia disputas de poder típicos da nova era. 0 Estado é chamado a intervir também nesse campo, como único instrumento capaz de arbitrar interesses profundamente divergentes, e incorporar, ao menos de forma parcial, demandas coletivas.

Por seu turno, o mesmo Estado, submetido à desqualificação neoliberal, demonstrou ser imprescindível à sobrevivência do sistema econômico-financeiro na sua configuração atual. 0 poder público tem atuado decisivamente em socorro de grandes instituições financeiras nas graves crises que assolam a economia global desde as últimas décadas do século passado, atenuando o efeito da inadimplência que atinge países inteiros, como no caso de nações da zona do euro. A contrapelo do receituário neoliberal, o auxílio de último recurso do poder público conduziu, no final da primeira década desse século, a uma relativa recuperação - não explicitamente admitida - do papel do Estado na economia, leia-se, como tábua de salvação de poderosas instituições envolvidas no bilionário jogo especulativo. Isso sem contar que as mais expressivas economias do leste asiático - a começar pela China - jamais seguiram os dogmas do livre mercado, e o Estado, ali, sempre exerceu papel de relevo na condução da economia e na direção dos investimentos.

No fundo das recentes crises, encontra-se o fato de a órbita financeira especulativa se descolar completamente da órbita real, a economia produtiva. A massa volátil de recursos que gira no mercado financeiro ultrapassa dez vezes o valor da produção global em bens e serviços. É preciso ressaltar também que os estados nacionais, embora sofrendo graves perturbações na sua organização e funcionamento, constituem peças estratégicas na produção das condições que tornam possível a globalização econômica e financeira. É principalmente no interior da máquina estatal que se gestam os mecanismos monetários, cambiais, comerciais, fiscais e jurídicos que conectam o mundo, por meio das políticas de desregulação dos mercados, privatização, livre trânsito de capitais e remoção de barreiras comerciais, as quais fazem da economia mundial contemporânea um mecanismo de concentração de renda, de privilégios à classe de rentistas e de criação de espaços para a absorção lucrativa dos capitais excedentes. Ao contrário de perderem poder, setores do Estado nacional assumem novas prerrogativas à custa da diminuição do espaço que políticas mais tradicionais ocupavam na balança política: é o caso da hipertrofia dos Ministérios da Fazenda e dos Bancos Centrais na estrutura dos governos, cuja relevância decisória chega a ultrapassar o próprio peso dos poderes legitimados pelo voto popular, como a presidência da república e o parlamento.

Tendências aparentemente paradoxais desafiam a compreensão. Por um lado, a geografia da desigualdade do capitalismo agrava as iniquidades intra e inter-regionais, marginalizando povos e nações dos supostos benefícios da globalização. A intensa onda migratória de países pobres de todos os continentes em direção à Europa ocidental, aos Estados Unidos e ao Canadá, provoca pressões populacionais de difícil assimilação nos grandes centros urbanos desses países, fomentando movimentos 
xenófobos e o fortalecimento de partidos de direita, alguns deles com claras conotações fascistas. Uma recomposição demográfica está em curso, e em poucas décadas teremos um perfil étnico bastante diferenciado dos assentamentos humanos e sua distribuição no planeta. 0 recrudescimento de ataques terroristas, a partir do início do século XXI, tem tudo a ver com essa realidade de iniquidades e agudos choques culturais.

Por outro lado, alguns países até então periféricos ascendem à condição de potências emergentes, ostentando taxas de crescimento superiores às dos países ricos e galgando degraus no caminho do desenvolvimento. Aos chamados "tigres" asiáticos nos anos 1970 e 1980, agora se agregam os BRICs, Brasil, Rússia, China e Índia, somados à África do Sul e um conjunto selecionado de países do terceiro mundo que elevam seus padrões de vida e o acesso aos bens que caracterizam as modernas economias contemporâneas. 0 poder global se volve mais heterogêneo. A China cresce cerca de 10\% ao ano há mais de três décadas, transformando-se na nova "oficina do mundo". A anatomia e a fisiologia da sociedade chinesa se modificam de forma vertiginosa. As cidades antigas e as cidades novas constituem um autêntico vórtice para onde todas as transformações confluem. Para o bem e para o mal, pois os fenômenos tão conhecidos das metrópoles ocidentais, como a poluição, 0 tráfego, os deslocamentos traumáticos de população e a especulação imobiliária, já fazem parte das urbanizações chinesas. Especula-se sobre a suposta hegemonia global que a China estaria prestes a exercer. Já os Estados Unidos são alvo de intensa controvérsia, girando sobre a sua decadência após o relativamente curto período de supremacia quase absoluta no fim da guerra fria. Outras forças políticas ganham relevância, como os blocos regionais, corporações privadas, poderes subnacionais, entidades da sociedade civil e até organizações ilegais (o narcotráfico, o contrabando de bens e pessoas, o comércio sexual, entre outras). Desse modo, assiste-se à crise do sistema de governabilidade mundial instaurado no pós-guerra. A ONU, em particular, é pressionada de todos os lados e não consegue dar resposta a tantas demandas contraditórias. Uma nova institucionalidade global é um desafio ainda sem solução.

Os paradigmas que pautaram a existência humana desde o advento da modernidade perdem sua eficácia para a construção de modelos do mundo ideal. Resultado aparente dos intensos deslocamentos geoeconômicos e geopolíticos que afetaram o planeta depois do último quarto do século passado, suas causas subjacentes devem ser identificadas em outros planos. 0 mais recente desses paradigmas, a concepção neoliberal, talvez nem se possa classificar desse modo, pois não constitui um sistema acabado e é quase toda ela uma elaboração político-ideológica para, utilizando-se da crise que se instala nas economias avançadas nos anos 1970, retirar poder dos trabalhadores organizados e instaurar o fluxo de capitais sem restrições institucionais de domínio público. Paradigma, sim, era a teoria neoclássica e a escola austríaca do século XIX, bem como todos os liberalismos que a antecederam e, no campo oposto - mas do mesmo modo herdeiro do racionalismo iluminista -, os marxismos de diversa índole. Os marcos desse abalo teórico nas metanarrativas que organizaram nossa apreensão do mundo e fixaram projetos de ação sobre a realidade concreta podem ser 
buscados primeiramente no campo da astrofísica, no interior do qual a teoria da relatividade de Albert Einstein (1879-1955) reposicionou as concepções mecanicistas provenientes de Isaac Newton (1643-1727) sobre o funcionamento do universo, e cujo desdobramento trouxe, por meio da teoria quântica das micropartículas, a inquietante evidência da incerteza fundamental que rege a vida no plano subatômico. As certezas são substituídas por um leque de probabilidades que formam coerências sempre transitórias, em processos distantes dos estados de equilíbrio.

0 movimento político e cultural dos anos 1960 foi outra contribuição fundamental à subversão dos valores herdados. A revolta contra concepções totalitárias, o racionalismo instrumental e os padrões da produção estética fundaram posições mais livres no campo cultural, bem como na esfera comportamental, rompendo com preconceitos intergeracionais e sexuais, entre outros. Contudo, essa mesma postura libertária abriu caminho, anos mais tarde, para a fragmentação na leitura da realidade, para o efêmero, o contingencial, a colagem instantânea das visões de mundo, sem preocupação com a coerência e a racionalidade intrínseca. Inaugura-se o pós-modernismo, como passou a ser conhecida a nova estética. 0 resultado disso tudo, ao lado da maior capacidade de decisão individual em contraposição à padronização e excessiva massificação de modelos anteriores - o que é inegavelmente positivo -, foi o absoluto predomínio da mercantilização sobre todos os aspectos da vida, a produção artística convertida em evento, espetáculo, propaganda, alienação, puro consumismo.

Em terceiro lugar, cabe enfatizar os efeitos que a reestruturação produtiva, ocorrida pelo impulso da revolução tecnológica e sob a orientação política ultraliberal, vem tendo sobre a organização social. 0 deslocamento relativo do trabalho assalariado como eixo estruturante das relações sociais e o concomitante surgimento de outras modalidades de trabalho, algumas delas regressivas - como a superexploração da mão de obra nas maquiladoras, o sistema de encomendas domiciliares (o putting-out system), o trabalho temporário ou parcial - deu origem a uma formação de classes mais heterogênea, desorganizando o movimento sindical na forma como ele se estabelecia na época fordista. Um mercado de trabalho mais segmentado reflete o avanço do trabalho dito imaterial, seja na indústria, seja nos serviços. Nesses, uma camada de profissionais de altos rendimentos, empregada em serviços especializados de elevada qualificação, cria um setor sofisticado nas grandes cidades para atendimento às suas necessidades de consumo conspícuo. A polarização laboral se acentua. A fragmentação das lutas por direitos cívicos e a geração de inúmeras "políticas de identidade", se por um lado permitiu a expressão de minorias e de demandas específicas, por outro diminuiu o peso político das reivindicações sociais e sua representação no aparelho de Estado.

Enfim, o começo do terceiro milênio encontra a humanidade com avanços notáveis no terreno científico e tecnológico, mas com enormes problemas, velhos e novos, por resolver. Parece até que as conquistas obtidas desafiam os povos com dilemas ainda mais difíceis a serem enfrentados. E não fica claro que muitos desses dilemas estão diretamente relacionados ao sistema político e econômico sob o qual vivemos, que tem no lucro seu motivo determinante, assim como à forma como esse 
impulso pelo ganho rápido tem sido socialmente gerido. Uma das consequências dramáticas do consumo perdulário das riquezas naturais é sentida pela deterioração rápida das condições de reprodução da vida na Terra. A mudança climática no planeta é decorrência de um padrão de crescimento econômico baseado na queima de combustíveis fósseis e na deflorestação. Se na atual conformação esse padrão revela-se insustentável, mais ainda o é se generalizado para a totalidade dos países, pelo efeito que provoca sobre a camada de ozônio e o consequente aquecimento global. Por mais que a economia contemporânea alargue o consumo do espaço eletrônico, as pessoas têm uma existência física e respondem a estímulos materiais, que precisam ser satisfeitos por bens e serviços concretos. Em suma, talvez uma das tarefas mais importantes que desafiam o futuro humano seja recuperar o sentido do público, a esfera coletiva da existência, o que impõe reformar o Estado, dotando-o de transparência, mecanismos de gestão participativa e descentralizada e do reforço dos instrumentos de regulação da economia e do mercado. Para tanto, a democratização e o criativo uso do espaço digital afiguram-se imprescindível. 0 rumo que os acontecimentos tomarão, a despeito de imprevisíveis, dependerá da energia dos grupos de pressão sociais, do poder de influência dos interesses permanentes da humanidade sobre a ganância dos detentores da riqueza privada. Acima de tudo, na perspectiva da radical reorganização do espaço humano vital, cabe encarar corajosamente a questão fundamental: avanços científicos para quê? $\mathrm{E}$, para quem?

\section{Ricardo Carlos Gaspar}

Pontifícia Universidade Católica de São Paulo, Faculdade de Economia e Administração, Departamento de Economia. São Paulo/SP, Brasil.

ricgaspar@gmail.com

\section{Referências}

ANDERSON, P. (1992). O fim da história: de Hegel a Fukuyama. Rio de Janeiro, Jorge Zahar.

ARRIGHI, G. (1996). O longo século XX: dinheiro, poder e as origens do nosso tempo. Rio de Janeiro, Contraponto; São Paulo, Unesp. (2008). Adam Smith em Pequim: origens e fundamentos do século XXI. São Paulo, Boitempo.

BOCCHI, J. I. (2000). Crises capitalistas e a escola francesa da regulação. Pesquisa \& Debate, v. 11, n. 1, p. 17. São Paulo, Programa de Estudos Pós-Graduados em Economia Política, PUC-SP.

BRAUDEL, F. (1987). A dinâmica do capitalismo. Rio de Janeiro, Rocco. 
BRENNER, N. (2004). New state spaces: urban governance and the rescaling of statehood. Nova York, Oxford University Press. (ed.) (2014). Implosions/explosions: towards a study of planetary urbanization. Berlin, GE, Jovis Books.

CHANG, H.-J. (2003). Globalisation, economic development and the role of the state. Londres, Zed Books; Penang, Third World Network.

(2004). Chutando a escada: a estratégia do desenvolvimento em perspectiva histórica. São Paulo, Unesp.

CHESNAIS, F. (org.). (2005). A finança mundializada: raízes sociais e políticas, configuração, consequências. São Paulo, Boitempo.

FIORI, J. L. (org.). (1999). Estados e moedas no desenvolvimento das nações. Petrópolis, Vozes.

FIORI, J. L. e MEDEIROS, C. A. (orgs.). (2001). Polarização mundial e crescimento. Petrópolis, Vozes.

FURTADO, C. (1999). O capitalismo global. Rio de Janeiro, Paz e Terra.

HARVEY, D. (1996). Condição pós-moderna: uma pesquisa sobre as origens da mudança cultural. São Paulo, Loyola.

(2006). Spaces of global capitalism: towards a theory of uneven geographical development. Londres/Nova York, Verso.

(2011). O enigma do capital e as crises do capitalismo. São Paulo, Boitempo.

HIRST, P. e THOMPSON, G. (1998). Globalização em questão. Petrópolis, Vozes.

HOBSBAWM, E. (1995). Era dos extremos: o breve século XX: 1914-1991. São Paulo, Companhia das Letras.

JAMESON, F. (1991). Post modernism, or, the cultural logic of late capitalism. Durham, NC., Duke University Press.

MASSEY, D. (2005). For space. Londres, Sage Publications.

PIPITONE, U. (2003). Ciudades, naciones, regiones: los espacios institucionales de la modernidad. México, Fondo de Cultura Económica.

SANTOS, M. (2001). Por uma outra globalização: do pensamento único à consciência universal. Rio de Janeiro, Record.

SASSEN, S. (2001). The global city: London, New York, Tokyo. New Jersey, Princeton University Press. (2007). Una sociología de la globalización. Buenos Aires, Katz.

SCOTT, A. (2012). A world in emergence: cities and regions in the 21st. century. Cheltenham/UK; Northampton/USA, Edward Elgar Publishing.

SILVER, B. J. e ARRIGHI, G. (2014). “O duplo movimento” de Polanyi: comparação da hegemonia da belle époque britânica e estadunidense. Revista Eletrônica de Estudos Urbanos e Regionais e-metropolis, n. 16, ano 5. Rio de Janeiro, Observatório das Metrópoles.

SMITH, N. (2008). Uneven development: nature, capital, and the production of space. Athens, GE, University of Georgia Press. 
TAVARES, M. C. e FIORI, J. L. (orgs.). (1997). Poder e dinheiro: uma economia política da globalização. Petrópolis, Vozes.

TILLY, C. (1996). Coerção, capital e estados europeus: 1990-1992. São Paulo, Edusp.

UNFPA (2010). State of the world population 2010: from conflict and crisis to renewal: generations of change. Nova York, United Nations Population Fund.

WALLERSTEIN, I. (2001). Capitalismo histórico e civilização capitalista. Rio de Janeiro, Contraponto.

Texto recebido em 26/jun/2014

Texto aprovado em 14/set/2014 